\title{
Interleukin-1 expression by neutrophils in rheumatoid arthritis
}

\author{
Julie A Quayle, Susan Adams, Roger C Bucknall, Steven W Edwards
}

\begin{abstract}
Objective-To determine if neutrophils from blood and synovial fluid of patients with rheumatoid arthritis and other joint

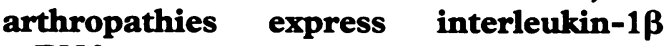
mRNA.

Methods-RNA was isolated from neutrophils from patient and control blood, and synovial fluid of patients, probed in northern blots, and quantified by densitometry. It was also isolated and analysed from control blood neutrophils after incubation in vitro with granulocyte macrophage colony stimulating factor (GM-CSF).

Results-Neutrophils from the synovial fluid of patients with rheumatoid arthritis contained low levels of mRNA for interleukin-1 $\beta$-between 0.1 and $2 \%$ of those observed during stimulation of control neutrophils with GM-CSF for one hour. Higher levels (4-40\% of the maximal GM-CSF values) were observed in blood neutrophils from patients with rheumatoid arthritis.

Conclusions-Neutrophils contribute to the cytokine network in rheumatoid arthritis. In some circumstances, activation of transcription may occur within the circulation of these patients.
\end{abstract}

(Ann Rheum Dis 1995; 54: 930-933)

In rheumatoid arthritis, the normally acellular joint fluid is infiltrated by a variety of immune cells, including $\mathrm{T}$ and $\mathrm{B}$ lymphocytes, mononuclear phagocytes, and neutrophils. ${ }^{1}$ During active disease, most of the infiltrating leucocytes are neutrophils and these have been activated in situ to release toxic reactive oxidants and granule enzymes. ${ }^{2}{ }^{3}$ Rheumatoid synovial fluid contains many cytokines which may be produced by mononuclear phagocytes and endothelial cells. However, it is known also that neutrophils can secrete a variety of cytokines, ${ }^{4-8}$ the amounts secreted being generally between five and 10-fold less (on a cell basis) than levels produced by mononuclear phagocytes. Nevertheless, because neutrophils can infiltrate tissues in vast numbers, neutrophil derived cytokines are pathophysiologically important.

We have investigated whether neutrophils contribute to interleukin-1 $\beta$ expression in rheumatoid disease. This cytokine is present in high concentrations within diseased joints and is implicated in disease pathology. ${ }^{910}$ It has been shown that a variety of proinflammatory mediators induce transient expression of this cytokine in human neutrophils. ${ }^{811} \mathrm{~A}$ recent investigation of interleukin-1 $\beta$ expression by rheumatoid neutrophils failed to detect ex vivo protein secretion in synovial cells, but the protein was detected in some blood neutrophils from rheumatoid patients. ${ }^{12}$ We have measured interleukin-1 $\beta$ mRNA in blood and synovial fluid neutrophils from patients with a variety of joint arthropathies.

\section{Materials and methods}

PATIENTS

We studied 26 patients attending the rheumatology clinics at the Royal Liverpool University Hospital, all with classical or seropositive rheumatoid arthritis (American Rheumatism Association criteria). Others examined were: two patients with seronegative polyarthritis, two with ankylosing spondylitis, one with Lyme's disease, and one with psoriatic arthritis. All were receiving non-steroidal anti-inflammatory drugs and none received steroids within the previous six months.

\section{PREPARATION OF NEUTROPHILS}

Neutrophils were isolated from buffy coats by sedimentation in dextran/Ficoll-Hypaque, as described previously. ${ }^{13}$ Neutrophils were also isolated from the blood and synovial fluid of patients with rheumatoid arthritis and other joint arthropathies as described previously. ${ }^{23}$ After purification, cells were suspended in RPMI 1640 medium and counted using a Fuchs-Rosenthal haemocytometer. Cell purity and viability were routinely assessed by Wright's staining and Trypan Blue exclusion and found to be $>97 \%$ and $>90 \%$, respectively, for all preparations.

RNA EXTRACTION

Neutrophils from buffy coats were incubated at $10^{7} \mathrm{cells} / \mathrm{ml}$ in RPMI 1640 with or without $50 \mathrm{U} / \mathrm{ml}$ granulocyte macrophage colony stimulating factor (GM-CSF) at $37^{\circ} \mathrm{C}$ for periods of up to 24 hours. After incubation for 1, 2, 4 and 24 hours, samples were removed for isolation of RNA. RNA was also extracted from patient or control blood neutrophils and patient synovial fluid neutrophils immediately after isolation. Cell pellets were suspended in $4 \mathrm{~mol} / \mathrm{l}$ guanidinium isothiocyanate, $5 \% \beta$-mercaptoethanol, $50 \mathrm{mmol} / / \mathrm{EDTA}, 50 \mathrm{mmol} / \mathrm{l}$ Tris, $\mathrm{pH}$ $7 \cdot 0$, and lysed by being drawn through a 23 gauge needle to shear chromosomal DNA. The suspension was layered onto a caesium chloride $(\mathrm{CsCl}) / \mathrm{EDTA}$ gradient $(5 \cdot 7 \mathrm{~mol} / 1 \mathrm{CsCl}$, 
$50 \mathrm{mmol} / 1$ EDTA, density $=1 \cdot 3995 \pm 0.001$ ) and centrifuged at $100000 \mathrm{~g}$ for 16 hours at $14^{\circ} \mathrm{C}$. The RNA pellet was suspended in diethylpyrocarbonate (DEPC) treated water and precipitated overnight with $0.3 \mathrm{~mol} / \mathrm{l}$ sodium acetate and $2.5 \mathrm{vol}$ ethanol at $-80^{\circ} \mathrm{C}$. The RNA was quantified by ultraviolet $\begin{array}{lllll}\text { spectroscopy (typically } 2 & \mu \mathrm{g} & \mathrm{RNA} & 10^{7}\end{array}$ neutrophils) and stored in $10 \mu \mathrm{g}$ aliquots at $-80^{\circ} \mathrm{C}$ as ethanol precipitates.

\section{NORTHERN BLOTS}

Aliquots of RNA $(10 \mu \mathrm{g})$ were subjected to electrophoresis on $1.2 \%$ agarose gels (containing $1 \%(\mathrm{v} / \mathrm{v})$ formaldehyde, $20 \mathrm{mmol} / \mathrm{l}$ 3- $N$-morpholinopropane sulphonic acid, $1 \mathrm{mmol} / / \mathrm{EDTA}, 5 \mathrm{mmol} / \mathrm{l}$ sodium acetate, $\mathrm{pH}$ 8.0) for 16 hours at $5 \mathrm{~mA}$. The gels were then stained in ethidium bromide and RNA was visualised by ultraviolet illumination. The RNA was then transferred by capillary blotting onto Zetaprobe GT nylon membrane (Bio$\mathrm{Rad}$ ) in $20 \times$ salt/sodium citrate (SSC) $(3 \mathrm{~mol} / \mathrm{l}$ $\mathrm{NaCl}, 0.3 \mathrm{~mol} / \mathrm{l}$ sodium citrate, $\mathrm{pH} 7 \cdot 0)$. Filters were baked at $80^{\circ} \mathrm{C}$ for 30 minutes, stored at room temperature in Saranwrap until use and then probed with labelled inserts prepared from the following cDNA clones obtained from the American Type Culture Collection (ATCC): interleukin-1 $\beta$ (ATCC 67024); v-fms (ATCC 41016); $\beta$-actin (ATCC 65128). The cDNA inserts were excised using appropriate restriction endonucleases and isolated from vector DNA by electrophoresis in low melting point agarose. Each insert (50-100 ng) was radiolabelled by random primed labelling using $25 \mu \mathrm{Ci}$ $\left[{ }^{32} \mathrm{P}\right]$-cytidine triphosphate (CTP) for 20 hours at $16^{\circ} \mathrm{C}$. Unincorporated $\left[{ }^{32} \mathrm{P}\right]-\mathrm{CTP}$ was removed from the labelled cDNA using Nuctrap columns (Stratagene). Radioactivity incorporated was typically $>10^{8} \mathrm{cpm} / \mu \mathrm{g}$ DNA. The filters were prehybridised for 30 minutes at $65^{\circ} \mathrm{C}$ in $0.25 \mathrm{~mol} / 1 \mathrm{Na}_{2} \mathrm{HPO}_{4} \cdot 7 \mathrm{H}_{2} \mathrm{O} / 7 \%$ sodium dodecyl sulphate (SDS), $\mathrm{pH} 7 \cdot 2$, and then hybridised with the probe for 16-20 hours in the same buffer at $65^{\circ} \mathrm{C}$. Filters were washed in $20 \mathrm{mmol} / 1 \mathrm{Na}_{2} \mathrm{HPO}_{4} \cdot 7 \mathrm{H}_{2} \mathrm{O} / 5 \% \mathrm{SDS}, \mathrm{pH}$ $7 \cdot 2$, twice for 30 minutes at $65^{\circ} \mathrm{C}$, followed by two 10 minute washes in $20 \mathrm{mmol} / \mathrm{l}$ $\mathrm{Na}_{2} \mathrm{HPO}_{4} \cdot 7 \mathrm{H}_{2} \mathrm{O} / 0 \cdot 1 \%$ SDS at the same temperature. They were then blotted dry, wrapped in Saranwrap and exposed to $x$ ray film (Fuji RX) for 24-48 hours. After autoradiography, probes were removed by heating the filters to $95^{\circ} \mathrm{C}$ in $0.1 \times \mathrm{SSC}$ containing $0.5 \% \mathrm{SDS}$, twice for 20 minutes. After autoradiographic confirmation of removal of the probe, the filters were reprobed.

\section{MATERIALS}

Dextran T500 and Ficoll-Hypaque were from Pharmacia (St Albans, UK), RPMI 1640 medium was from Flow Laboratories (Rickmansworth, UK), and the random labelling kit was from Boehringer (Lewes, UK). Zetaprobe was from Bio-Rad (Hemel Hempstead, UK), [ $\left.{ }^{32} \mathrm{P}\right]-\mathrm{CTP}$ from Amersham
(Little Chalfont, UK), and rGM-CSF was from Glaxo (Greenford, UK). The last was a non-glycosylated peptide with an activity of $\geq 1.5 \mathrm{mU} / \mathrm{mg}$ in the AML-193 proliferation assay. All other reagents were of the highest purity available.

\section{Results}

Addition of $50 \mathrm{U} / \mathrm{ml}$ GM-CSF to normal blood neutrophils for one hour induced a large increase in mRNA levels for interleukin-1 $\beta$ (fig 1A-C, lane 1). However, in mRNA of synovial fluid neutrophils from 21 patients with rheumatoid arthritis, transcripts for interleukin-1 $\beta$ were present at low, but detectable levels (fig $1 \mathrm{~A}-\mathrm{C}$, lanes $2-7$ ), being $0 \cdot 1-2 \%$ of levels maximally induced by exposure of control blood neutrophils (from healthy donors) to GM-CSF in vitro. To obtain the results shown in this figure, the filters were exposed to film for seven days in order to visualise these low hybridisation signals. Similar levels of mRNA for interleukin- $1 \beta$ were detected in neutrophils from the synovial fluid of two patients with seronegative polyarthritis, but none was detected in neutrophils from two patients with ankylosing spondylitis, one with Lyme's disease or one with psoriatic arthritis (data not shown).

When the filters were stripped and probed for $\mathrm{v}$-fms mRNA (the macrophage colony stimulating factor receptor), no hybridisation signals were detected (data not shown), thus

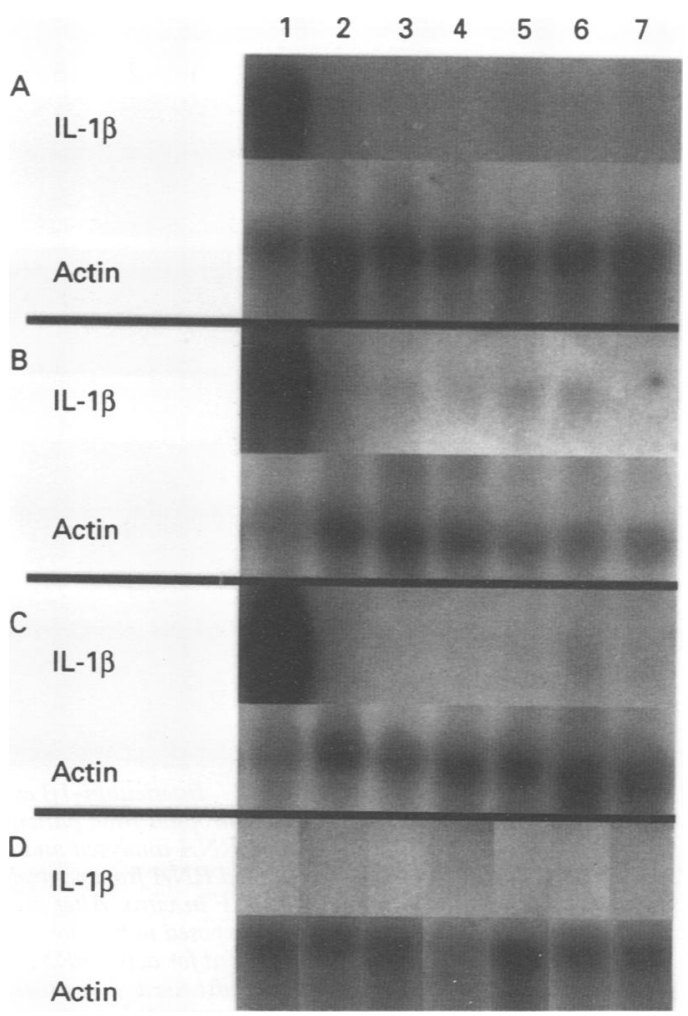

Figure 1 Interleukin-1 $\beta$ mRNA levels in control blood and patient synovial fluid neutrophils. A-C: Analysis of $R N A$ from control blood neutrophils after incubation with GM-CSF for one hour in vitro (LANE 1) and neutrophils from the synovial fluid of patients with rheumatoid arthritis (LANES 2-7) (different controls and different patients) Filters exposed to film for seven days then stripped and probed for levels of actin $m R N A$. D: RNA isolated immediately after extraction of neutrophils from control venous blood (LANES 1-3), or from buffy coats (LANES 4-7). Transcript sizes: interleukin-1 $\beta 1 \mathrm{~kb}$; actin $1 \cdot 3 \mathrm{~kb}$. 
excluding the possibility that monocyte contamination of the neutrophil preparations was contributing to the interleukin-1 $\beta$ signal. However, when the filters were reprobed for actin mRNA, the hybridisation signals were equal to or greater than those obtained with control blood neutrophils after GM-CSF treatment in vitro.

Transcripts of mRNA for interleukin- $1 \beta$ were detected in blood neutrophils of patients with rheumatoid arthritis at greater levels than those detected in paired synovial fluid neutrophils. Values for the blood neutrophils (expressed as a percentage of the maximal levels obtained after treatment of control blood neutrophils for one hour in vitro with GM-CSF) were: $42 \%, 23 \%, 20 \%, 16 \%, 5 \%$, and $4 \%$. Figure 2 shows northern blots of blood neutrophils from five patients, together with the paired synovial fluid neutrophil samples, from filters exposed to film for two days to develop the interleukin- $1 \beta$ signal. In two patients with seronegative arthritis and two patients with ankylosing spondylitis, the hybridisation signals for interleukin $-1 \beta$ mRNA in the blood neutrophils were undetectable (data not shown).

\section{Discussion}

Much evidence indicates that neutrophils contribute to the cytokine cascade during inflammation. Previous work has shown that $\mathrm{mRNA}$ for interleukin-1 $\beta$ is not expressed in

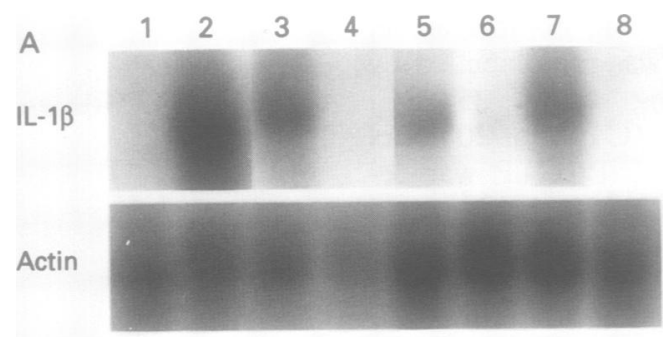

B

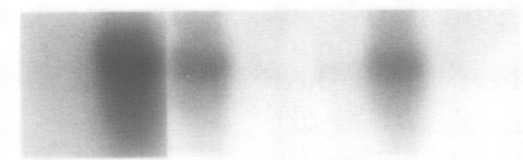

Actin

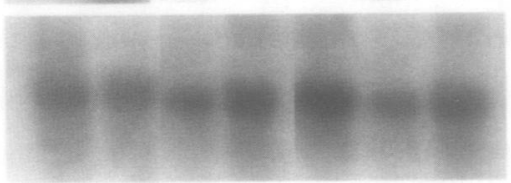

Figure 2 Interleukin-1 $\beta$ expression in blood and synovial fuid neutrophils from patients with rheumatoid arthritis. Patient RNA analysed and quantified on blots that also contained RNA from control blood neutrophils treated with $G M-C S F$ in vitro. After probing for interleukin-1 $\beta \mathrm{mRNA}$ (filters exposed to film for two days), filters were stripped and probed for actin mRNA. A: LANE 1, control blood neutrophils; IANE 2, control blood neutrophils incubated for one hour with $50 \mathrm{U} / \mathrm{ml}$ GM-CSF; IANH 3, blood neutrophils from patient $1 ; L A N E 4$, synovial fluid neutrophils from patient $1 ; L A N E 5$, blood neutrophils from patient 2; LANE 6, synovial fluid neutrophils from patient 2 ; patient 2 , blood neutrophils from patient $3 ;$ LANE 8 , synovial LANE 7, blood neutrophils from patient $3 ;$ LANE 8 , synovial
fluid neutrophils from patient 3 . B: LANE 1, control blood neutrophils; LANE 2, control blood neutrophils incubated for one hour with $50 \mathrm{U} / \mathrm{ml}$ GM-CSF; LANE 3, blood neutrophils from patient 4; LANE 4, synovial fluid neutrophils from patient 4; LANE 5, control blood neutrophils; LANE 6, blood neutrophils from patient 5; LANF 7, synovial fluid neutrophils from patient 5 . blood neutrophils, but expression is increased rapidly upon exposure to agents such as GM-CSF. We could not detect transcripts for this cytokine in more than 20 preparations of neutrophils freshly isolated from venous blood or buffy coats of healthy controls (for example, figure $1 \mathrm{D}$ ), confirming that interleukin-1 $\beta$ is not expressed in blood neutrophils under normal circumstances.

Some reports indicate that synovial fluid neutrophils do not produce interleukin- $1 \beta,{ }^{12}$ whereas others have shown that they do. ${ }^{1+}$ In addition, synovial fluid neutrophils express interleukin- 8 and interleukin-1 receptor antagonist (interleukin-1 ra). ${ }^{15-17}$ Expression of interleukin-1 ra occurs in blood neutrophils and expression is upregulated by a variety of proinflammatory agents such as lipopolysaccharide, GM-CSF, and tumour necrosis factor. Levels of interleukin-1 ra production by activated neutrophils can approach those produced by lipopolysaccharide treated monocytes. $^{18}$ Thus synovial fluid neutrophils may exert both pro- and anti-inflammatory effects, depending upon local circumstances within the joint.

The results presented here indicate low, but detectable levels of mRNA for interleukin-1 $\beta$ in synovial fluid neutrophils from patients with rheumatoid arthritis. In control neutrophils exposed to GM-CSF in vitro, levels of interleukin-1 $\beta$ mRNA were maximal within one hour of stimulation and then declined rapidly to basal levels, being only about $10 \%$ of maximum four hours after stimulation and undetectable by 24 hours (data not shown). Low levels of mRNA for interleukin- $1 \beta$ in a population of synovial fluid neutrophils may thus indicate heterogenous expression (only a small number of cells express), or may be a reflection of a post-stimulation value - that is, levels of mRNA are returning to a post-stimulatory value. It was therefore somewhat surprising to discover much higher levels of mRNA for interleukin $-1 \beta$ in neutrophils isolated from the blood of rheumatoid arthritis patients. Levels of this transcript in some patients were comparable to those observed two hours after stimulation of control neutrophils with GM-CSF in vitro. Because of the very transient nature of increased mRNA levels, this observation indicates that blood neutrophils of these patients are continuously exposed to agents that stimulate transcription of interleukin-1 $\beta$. Previous work has shown that production of interleukin- $1 \beta$ protein follows $4-18$ hours after stimulation by GM-CSF. ${ }^{11} 18$ Whether increased interleukin- $1 \beta$ mRNA levels in blood neutrophils lead to systemic protein secretion, or to production once they are recruited into the joint, remains to be determined. Our results imply that activation of interleukin- $1 \beta$ expression by neutrophils in rheumatoid disease can occur within the circulation before the cells enter diseased joints.

We thank the Arthritis and Rheumatism Council for generous financial support. SA held an SERC research studentship.

1 Feldman M, Brennan F M, Chantry D, it al. Cytokine production in the rheumatoid joint: implications for treatment. Alun Rheum Dis 1990; 49: 480-6. 
2 Nurcombe H L, Bucknall R C, Edwards S W. Neutrophils isolated from the synovial fluid of patients with rheumatoid arthritis: priming and activation in vivo. $A n n$ Rheum Dis 1991; 51: 147-53.

3 Edwards S W, Hughes V, Barlow J, Bucknall R. Immunological detection of myeloperoxidase in synovial fluids from patients with rheumatoid arthritis. Biochem $₹ 1988$; 250: 81-5.

4 Edwards S W. Biochemistry and physiology of the neutrophil. New York: Cambridge University Press, 1994; 299.

5 Lindemann A, Riedel D, Oster W, Ziegler-Heitbrock H W L Mertlesmann R H, Hermann F. Granulocytemacrophage colony-stimulating factor induces cytokine secretion by human polymorphonuclear leukocytes. $f$ Clin Invest 1989; 83: 1308-12.

6 Djeu J Y, Serbousek D, Blanchard D K. Release of tumor necrosis factor by human polymorphonuclear leukocytes. Blood 1990; 76: 1405-9.

7 Streiter R M, Kasahara K, Allen R M, et al. Cytokineinduced neutrophil-derived interleukin-8. Am $\mathcal{f}$ Pathol 1992; 141: 397-407.

8 Lindemann A, Riedel D, Oster W, et al. Granulocyte/ macrophage colony-stimulating factor induces interleukin 1 production by human polym

9 Pettipher E R, Henderson B, Moncada S, Higgs G A. Leucocyte infiltration and cartilage proteoglycan loss in immune arthritis in the rabbit. Br $\mathcal{F}$ Pharmacol 1988; 95: 169-76.

10 Arner A C, Pratta M A. Independent effects of interleukin-1 on proteoglycan breakdown, proteoglycan synthesis, and prostaglandin $E_{2}$ release from cartilage in organ culture. Arthritis Rheum 1989; 32: 288-97.
11 Marucha P T, Zeff R A, Kreutzer D L. Cytokine-induced IL-1 $\beta$ gene expression in the human polymorphonuclear leukocyte. Transcriptional and post-translational regulation by tumor necrosis factor and IL-1. F Immunol 1991; 147: 2603-8.

12 Dularay B, Westacott C I, Elson C J. IL-1 secreting cell assay and its application to cells from patients with assay and its application to cells from patients with

13 Edwards S W, Swan T F. Regulation of superoxide generation by myeloperoxidase during the respiratory burst of human neutrophils. Biochem $\mathcal{f} 1986 ; 237: 601-4$.

14 Beaulieu A D, McColl S R. Differential expression of two major cytokines produced by neutrophils, interleukin-8 and the interleukin-1 receptor antagonist, in neutrophils isolated from the synovial fluid and peripheral blood of patients with rheumatoid arthritis. Arthritis Rheum 1994; 37: 855-9.

15 Tiku K, Tiku M L, Liu S, Skosey J L. Normal human neutrophils are a source of a specific interleukin 1 inhibitor. F Immunol 1986; 136: 3686-92.

16 Malayak M, Smith M F J, Abel A A, Arend W P. Peripheral blood neutrophil production of interleukin-1 receptor antagonist and interleukin-1ß. $\mathcal{f}$ Clin Immunol 1994; 14: antagonist

17 McColl S R, Paquin R, Menard C, Beaulieu A D. Human neutrophils produce high levels of the interleukin 1 receptor antagonist in response to granulocyte/ macrophage colony-stimulating factor and tumor necrosis factor $\alpha$. F $\operatorname{Exp} M e d$ 1992; 176: 593-8.

$18 \mathrm{Re}$ F, Mengozzi M, Dinarello C A, Mantovani A, Colotta F. Expression of interleukin-1 receptor antagonist (IL-1 ra) by human circulating polymorphonuclear cells. Eur f Immunol 1993; 23: 570-3. 